\title{
Reaction on the Johannesburg Stock Exchange to major shifts in dividend policy
}

\author{
Narendra Bhana \\ Graduate School of Business, University of Durban-Westville, Private Bag X54001, Durban 4000, Republic of South Africa
}

Received 13 March 1991; accepled 7 May 1991

\begin{abstract}
The objective of this article is to examine the share market response to substantial changes in dividend policies for companies listed on the Johannesburg Stock Exchange. The results provide strong support for the information content of dividend hypothesis. Investors revise their expectations in response to announcement of significant dividend changes. The market reacts more dramatically to negative than to positive dividend changes. The JSE appears to be inefficient in reacting to the announcement of dividend changes; economically significant abnormal returns are observed for a period of up to 20 trading days after the event. A systematic trader in dividend changing shares woukd have earned significant abnormal returns even though the market effects large corrections before, and at the announcement date. This pattern is especially clear around dividend omissions and large dividend decreases.
\end{abstract}

Die doel van hierdie artikel is om die markseaksie wat volg op belangrike veranderinge in die dividendebeleid van maatskappye wat op die Johannesburgse Effektebeurs genoteer word, te ondersoek. Die bevindings bied sterk steun vir die gegewensinhoud van die dividende-hipotese. Beleggers wysig hul verwagtings na aanleiding van aankondigings van betekenisvolle dividendveranderinge. Die mark reageer meer dramaties op negatiewe as op positiewe dividendveranderinge. Dit blyk dat die Johannesburgse Effektebeurs ondoeltreffend reageer op die aankondiging van dividendveranderinge; abnormale opbrengste wat ekonomies belangrik is, word vir 'n tydperk van 20 dae warin sake gedoen word na die gebeurtenis waargeneem. 'n Handelaar wat sistematies handel dryf in aandele waarvoor dividendveranderinge aangekondig word, sal reeds betekenisvolle abnormale opbrengste verdien het al sou daar groot aanpassings op die mark voor of op die datum van aankondiging volg. Hierdie patroon is veral sigbaar waar dividende weggelaat word en waar groot afnames in dividende voorkom.

\section{Introduction}

The 'information content of dividends' hypothesis has emerged from the work of Lintner (1956) and Miller and Modigliani (1961). This hypothesis states that company managers use dividend announcements to signal their beliefs about the prospects of the firm. An announcement of an increase in the dividend rate reflects management's belief that the firm's earnings in the foresceable future will be sufficiently high to sustain payment at the increased rate. Similarly, an announcement of a dividend decrease occurs only when management is extremely pessimistic about the probability that future earnings will be sufficient to continue dividends at their present rate. The theoretical implication of the 'information content' hypothesis is that the announcement of a dividend (or a change in dividend) conveys information about management's assessment of the firm's prospects, that this information is different from other information provided by management, and this information may cause an immediate investor reaction, including but not limited to share price changes.

The validity of the dividend information hypothesis hinges on the belief that a firm's management often possesses priviledged information about the firm's future earnings potential and communicates this to the general investment community by altering the expected dividend. The difference between the actual dividend declared and that 'expected' by the market i.e. the unexpected change in dividends, purportedly is a signal that investors use to reassess their estimates of a security's value. Despite the theoretical importance of dividend announcements, this area has been a neglected field of study in South Africa. The purpose of this article is to examine investor behaviour around dividend announcement dates for securities listed on the Johannesburg Stock Exchange.

\section{Prevlous studies}

Empirical studies have examined the role dividends play in providing information to investors. Pettit (1972) found that dividend announcements convey valuable information. Wats (1973) and Gonedes (1978) however, came to the opposite conclusion, contending that unexpected dividend changes communicate no information beyond that reflected in other contemporaneous variables such as eamings. Laub (1976) and Peutit challenged Wats' findings, and Watts (1976) rebutued these challenges. All these prior studies are based primarily on monthly share prices and were not able to highlight any abnormal retums occurring just prior to the announcement of a dividend change.

Charest (1978) using daily retum data found that the announcement of a dividend increase generates an excess return of about $1 \%$. Because his study made no effort to remove the effect of contemporaneous earnings announcements, Charest concludes that his evidence did not necessarily reveal the presence of information in dividend announcements. Aharony and Swary (1980), also using daily data, documented a small but significant dividend announcement effect separate from the information impact of eamings announcements. Their analysis focused on dividend announcement dates that differ from eamings announcement dates by at least 11 days. For dividend increases they found a significant average excess return of about $1 \%$ over the 2 -day announcement period. Their study also suppons the semi-strong form of the efficient market hypothesis. There is no leakage of information prior to the dividend announcement and the full impact of the announcement is concentrated in the 2-day announcement period.

Asquith and Mullins (1983) analyzed 168 firms that either paid the first dividend in their corporate history or 
initiated dividends after a 10-year hiatus. Subsequent dividend increases for the same sample of firms were also investigated. The findings for both initial and subsequent dividends are consistent with the view that dividends convey unique, valuable information to investors. Asquith and Mullins (1983: 95) conclude that initiating a dividend policy does matter, probably as an information source, and that the market reaction is strong and positive.

Woolridge (1982) investigated whether investors reassessed their expectations about future profitability by revaluing their equity shares in reaction to unexpected dividend changes. The results showed that the market reacts to dividend information (both positive and negative) within a day of the announcement. These results also supported the notion of an efficient market in that a profitable short-term trading rule could not provide abnormal returns when transaction costs are considered. Woolridge (1982: 247) submitted that if a dividend change is expected by the market, the actual announcement does not provide additional information to the market.

Studies by Dielman and Oppenheimer (1984) and Banesh, Keown and Pinkerton (1984) examined the aggregate market response to four distinct groups of dividend announcements: a group increasing dividends by at least $25 \%$, a group making initial dividend payment, a group decreasing dividends by at least $25 \%$, and a group omitting dividends. Dielman and Oppenheimer found that on the day of the announcement and the day after the announcement, all four groups experience, on average, large and significant abnormal returns. The abnormal returns are positive for the groups initiating dividends and $25 \%$ dividend increases and negative for the groups with dividend omissions and $25 \%$ dividend decreases. Furthermore, the share price adjustment process continues up to a month following the announcement of a change in dividend policy. These results are confirmed in the investigation by Banesh, Keown and Pinkerton (1984). Both studies also observed that the market's reaction to unfavourable dividend announcements is much greater than for favourable announcements.

Dividend reductions and omissions usually follow persistently poor earnings performance. Ghosh and Woolridge (1989) analysed shareholder reaction to growth motivated dividend reductions and omissions. This investigation revealed that although growth announcements mitigate the capital loss induced by dividend decreases, the stock-market response to growth-oriented dividend reductions is still strongly negative. It was also shown that the capital loss suffered by investors is significantly reduced when dividend reductions are accompanied by stock dividend (bonus share issues). Ghosh and Woolridge (1989: 33) conclude that shareholders find the immediate benefits of stock dividends more attractive than the potentially higher future rewards of investment opportunities. Shareholders' lack of information about the profitability of the investment opportunities is a potential explanation of the ineffectiveness of growth announcements as signals of future performance.

Knight and Affleck-Graves (1987) evaluated the dividend signalling associated with dividend announcements by 41 companies listed on the Johannesburg Stock Exchange during the 1973-1980 period. Using the Fama-Babiak (1968) model, abnormal retums for the 21 weeks sur- rounding the week of the dividend announcements were analysed. The announcements with positive dividend forecast error wene grouped as the 'good news' portfolio and the announcements with negative forecast error were grouped as the 'bad news' portfolio. Both portfolios obtained significant positive reaction in the week and the subsequent ten weeks following the dividend announcement. Knight and Affleck-Graves (1987: 84) conclude that the empirical evidence suggests that dividend announcements on the JSE convey little or no information to the market over and above that contained in the eamings announcements. A further conclusion is that the signalling role of dividends is an unlikely explanation of the dividend phenomenon on the JSE.

Venkatesh (1989) has reviewed the current research into the signalling role of dividends and reports that there now appears to be a consensus that both eamings and dividend announcements have information content. The surprising results of the Knight and Affleck-Graves study could well be due to several methodological shortcomings. First, the Fama-Babiak model requires the use of a forecasting technique to capture investors' dividend expectations. An error in the regression analysis could produce significant forecasting error leading to a miscategorizing of dividend changes into their expected and unexpected components. Forecasting errors could eventually lead to an inconsistent composition of the 'good news' and 'bad news' portfolios. Second, the inadequate identification and control of simultaneous eamings announcements has raised the possibility of contaminated results. Third, by using weekly return data, any abnormal price changes associated with an event occurring during the same week as the dividend announcement date are aggregated into the weekly return. For this reason, the use of daily returns become critical to detect price movements occurring prior to the announcement date. These shortcomings have been specifically addressed in the current investigation of the signalling role of dividends in South Africa.

\section{Sampling procedure}

The methodological approach used in this study is similar to that of Aharony and Swary (1980). This approach recognises that eamings and dividend announcements often occur simultaneously. Controlling for these contemporaneous announcements and eliminating contaminated cases significantly improves the procedure. The announcement date for each company's dividend change and the date of the closest interim and/or annual earnings announcement were obtained directly from the companies concerned. To be included in the final sample, a dividend announcement had to be at least ten trading days removed from the closest eamings announcement. In this way, possibly contaminated abnormal returns related to concurrent earnings announcements are eliminated. The choice of ten days is consistent with the methodology employed by Aharony and Swary (1980).

Instead of examining an aggregated sample of all dividend changes, this investigation is confined to four subsamples of major dividend policy shifts. This approach avoids the problem of miscategorizing dividend changes 
into their expected and unexpected components. The four subsamples were chosen using the following criteria:

1. Each company must have been listed on the JSE during the years 1970-1988.

2. Each company must have had a major shift in dividend policy (between 1970-1988) after at least two years of stable dividend pattern. A company's dividend policy is considered 'stable' only if its cash dividend stream, adjusted for any capitalization changes, was unchanged for at least two years. 'Major shift' refers to either an omission, a resumption of dividends or a 'large' increase/decrease in the yearly dividend rate of at least $40 \%$. Information related to dividend changes was obtained from the Bureau of Financial Analysis of the University of Pretoria.

3. Daily return data must have been available for each company for 102 trading days surrounding the announcement date (51 trading days ocurring before and 51 trading days on and after the announcement date). The daily retum data was obtained from the JSE Daily Master Tape.

4. Random samples of 40 companies were selected for each of the four groups that represented 'major shift' in dividend policy.

'Large' dividend policy change refers to companies that increased/decreased dividends by at least 25 cents per share and by at least $40 \%$ after a period of two years of stable dividend pattern. Therefore, the new yearly dividend rate is either less than $60 \%$ or more than $140 \%$ of the previous rate. The dual classification of both rand value and percentage change eliminates any company that made small rand value changes that result in large percentage increases or decreases.

\section{Research methodology}

According to the capital asset pricing model (CAPM) developed by Sharpe (1964) and Lintner (1965), there should be, in a well-functioning capital market environment, a linear relationship between the expected retum on a security and the security's contribution to portfolio risk. Despite the critique by Roll (1977) regarding the empirical testability of the CAPM, all studies of market efficiency must either assume such a model, or else make equally strong assumptions about the stability of the return-generating process. A commonly used technique is the Market Model (Bowman, 1983), which employs simple linear regression to estimate the required risk-adjusted return for a security. The abnormal returns associated with major shifts in dividend policy were estimated by means of the Market Model:

$R_{j t}^{*}=\alpha_{j}+\beta_{j} R_{m t}+\bar{e}_{j t}$

where $\mathbf{R}_{\mathrm{jt}}=$ the expected return on share for the period $t$; $\alpha_{j}, \beta=$ the intercept and slope respectively of the linear relationship between the return for share $j$ and the returns for the general market; $R_{\mathrm{mt}}=$ return on the market portfolio represented by the JSE Overall Actuaries Index during period $\mathrm{t} ; \overline{\mathrm{c}}_{\mathrm{jl}}=$ disturbance term or residual.

We can attribute deviations of observed $R_{j t}$ from those stipulated by the Market Model i.e. $\mathbf{R}_{\mathrm{j}}^{*}$ to whatever special or extraordinary circumstances surrounding security $\mathbf{j}$ during the interval considered - temporary disequilibria, some inevitable random noise in the underlying return-generating process, or the signalling effect of the dividend announcement. The objective is to examine the deviations around the vicinity of the dividend announcement and to measure $a b-$ normal price changes during this period.

The competing hypotheses tested in this study can be stated as:

Ho : Investors' expectations are unaltered by announcements of significant dividend changes (no signalling effect).

H1 : Investors' revise their expectations in response to announcements of significant dividend changes (signalling effect).

To test the hypotheses, the variable of interest is the security's 'abnormal' or 'residual' return, defined as $\mathrm{e}_{\mathrm{jt}}=$ $R_{\mathrm{jt}}-\mathrm{R}_{\mathrm{jt}}$. If the mean value of this quantity across the array of dividend changes is non-zero (positive for dividend resumptions and large increases; negative for dividend omissions and large decreases) and statistically significant, we can draw an inference that the signalling role of dividends explains the dividend phenomenon.

Daily share prices were calculated for a period of 41 days surrounding each dividend announcement. The standard reference date for each security $(t=0)$ is the day on which a dividend announcement is made. In every instance, residuals were computed for the 20 trading-day period prior to the dividend announcement date and the 21 trading-day period on and after the announcement date. Thus the analytical interval runs from day $t=-21$ through $t=+20$, spanning a variety of different calendar periods but structured always around the applicable dividend announcement date.

The daily average residuals were estimated from the Market Model and may be expressed as:

$e_{i}=\frac{1}{40} \sum_{j} \stackrel{40}{=} \hat{e}_{j t} \quad t=-20,-19, \ldots-\cdots, 20$

A total of 41 average residuals were calculated i.e. for the 20 trading-day period prior to the dividend announcement date and the 21 trading-day period on and after the announcement date. These average residuals are used as the basis for examining abnormal share price movements around the dividend announcement date. The cumulative average residual (CAR), defined as the sum of the previous daily average residuals, was calculated for each trading day of study and may be written as:

$\operatorname{CAR}_{\mathrm{t}}=\mathrm{e}_{\mathrm{t}}+\mathrm{CAR}_{\mathrm{t}-1}$

$t=20,-19$

If one assumes that there are no unusual share price movements prior to the dividend announcement date, one can expect that both $\mathrm{e}_{\mathrm{h}}$ and $\mathrm{CAR}_{\mathrm{t}}$ would fluctuate randomly about zero. However, if material information is associated with an announced dividend change, the resulting share price change would be reflected by a deviation of the daily 
average residuals from zero and a corresponding increase or decrease in CAR.

The methodology developed by Brown and Warner (1980) can be used for a comparative period analysis over selected intervals around the dividend announcement. Comparative period analysis is employed to examine abnormal performance over four time periods i.e. (1) -20 to -11 days, (2) -10 to -2 days, (3) +2 to +10 days, and (4) +11 to +20 days, respectively. Excluding days $-1,0$ and +1 allows inferences relating to the market's anticipation of forthcoming announcements and to any adjustments that transpire subsequent to the immediate reaction to the news.

There is considerable uncertainty in determining when the dividend announcement is made public. Day $t=0$ is the day the news of the dividend is published in the news media. In many cases, however, the news is announced the previous day, $t=-1$; and reported the next day. If a dividend is announced before the market closes, then the market's response to the news actually predates the announcement day by one. If the news is announced after the market closes, the market will respond the next day and the announcement day is indeed zero. Thus in reality there is a 2-day announcement 'day', $t=-1$ and $t=0$. A 2-day excess return is necessary to capture the entire impact of a dividend announcement.

\section{Empirical results}

The share price performance of four distinct groups of securities are examined for 102 trading days surrounding the announcement date. For each group of securities, both the daily average residuals and the $C_{A R}$ produced a random pattern until approximately 20 days prior to the dividend announcement. Similarly, very few statistically significant daily average residuals and $C_{A R}$ values are found after a 20-day period following the dividend announcement. Therefore, for analytical purposes the market reaction is analysed for the 20-day periods preceding and following the announcement of dividends.

The daily average residuals and $\mathrm{CAR}_{\mathbf{Y}}$ for a group of securities that decreased their dividends by at least $40 \%$ and a group of securities that omitted their dividends are shown in Tables 1 and 2 respectively. As these groups can be expected to produce unfavourable market reaction they can be referred to as 'negative news' groups. There was a dramatic market reaction to omitted dividends as well as large dividend decreases. The average abnormal return for the announcement days ( day -1 and day 0 ) is $-8,2 \%$ for large dividend decreases and $-10,5$ for omitted dividends. In each case, the average residual is significantly different from zero at the 0,01 level of significance. This implies that the relevant information is transmitted to the market when large reductions in dividends are announced.

The results indicate that significant market reaction occur on the dividend announcement date, even though the market has already made substantial negative adjustments during the month preceding the news releases. In the 19 trading days preceding the dividend announcement date, the CAR values declined by $11,3 \%$ for the large dividend decrease sample and by $13,3 \%$ for the omitted dividends. For the
Table 1 Investment return residuals for large dividend decrease sample (minimum decrease of $40 \%$ ) during 1970-1988

\begin{tabular}{|c|c|c|c|}
\hline Day & $\begin{array}{c}\text { Daily average } \\
\text { residual }\end{array}$ & T statistic & $\begin{array}{c}\text { Cumulative avernge } \\
\text { residual }\end{array}$ \\
\hline-20 & $-0 ; 150$ & $-0,396$ & $-0,150$ \\
\hline-19 & $+0,160$ & $+0,432$ & $+0,010$ \\
\hline-18 & $+0,251$ & $-0,648$ & $+0,261$ \\
\hline-17 & $-0,260$ & $-0,651$ & $+0,001$ \\
\hline-16 & $-0,186$ & $-0,437$ & $-0,185$ \\
\hline-15 & $-0,195$ & $-0,460$ & $-0,380$ \\
\hline-14 & $-0,255$ & $-0,662$ & $-0,635$ \\
\hline-13 & $-0,286$ & $-0,695$ & $-0,921$ \\
\hline-12 & $-0,385$ & $-0,836$ & $-1,306$ \\
\hline-11 & $-0,420$ & $-0,994$ & $-1,726$ \\
\hline-10 & $-0,512$ & $-1,120$ & $-2,238$ \\
\hline-9 & $-0,636$ & $-1,245$ & $-2,874$ \\
\hline-8 & $-0,815$ & $-1,365^{2}$ & $-3,689$ \\
\hline-7 & $-0,801$ & $-1,353^{\circ}$ & $-4,490$ \\
\hline-6 & $-0,720$ & $-1,305^{2}$ & $-5,210$ \\
\hline-5 & $-0,926$ & $-1,409^{\circ}$ & $-6,136$ \\
\hline-4 & $-1,350$ & $-1,664^{b}$ & $-7,486$ \\
\hline-3 & $-1,600$ & $-1,822^{b}$ & $-9,086$ \\
\hline-2 & $-2,187$ & $-3,015^{c}$ & $-11,273$ \\
\hline-1 & $-4,821$ & $-3,821^{c}$ & $-16,094$ \\
\hline 0 & $-3,335$ & $-3,360^{\circ}$ & $-19,429$ \\
\hline 1 & $-2,115$ & $-3,105^{c}$ & $-21,554$ \\
\hline 2 & $-1,750$ & $-2,123^{\mathrm{e}}$ & $-23,304$ \\
\hline 3 & $-1,110$ & $-1,132^{\circ}$ & $-24,414$ \\
\hline 4 & $-1,120$ & $-1,416^{\prime}$ & $-25,534$ \\
\hline 5 & $-0,721$ & $-1,320^{\circ}$ & $-26,255$ \\
\hline 6 & $-0,642$ & $-1,284^{2}$ & $-26,897$ \\
\hline 7 & $-0,501$ & $-1,109$ & $-27,398$ \\
\hline 8 & $-0,414$ & $-1,020$ & $-27,812$ \\
\hline 9 & $-0,313$ & $-0,810$ & $-28,125$ \\
\hline 10 & $-0,197$ & $-0,463$ & $-28,322$ \\
\hline 11 & $-0,235$ & $-0,540$ & $-28,557$ \\
\hline 12 & $-0,137$ & $-0,398$ & $-28,694$ \\
\hline 13 & $-0,101$ & $-0,340$ & $-28,795$ \\
\hline 14 & $-0,120$ & $-0,378$ & $-28,915$ \\
\hline 15 & $-0,116$ & $-0,360$ & $-29,031$ \\
\hline 16 & $-0,149$ & $-0,420$ & $-29,180$ \\
\hline 17 & $-0,080$ & $-0,218$ & $-29,260$ \\
\hline 18 & $-0,071$ & $-0,205$ & $-29,331$ \\
\hline 19 & $+0,165$ & $-0,462$ & $-29,166$ \\
\hline 20 & $-0,102$ & $-0,314$ & $-29,268$ \\
\hline
\end{tabular}

a: Daily average residual significant at the 0,90 level.

b: Daily average residual significant at the 0,95 level.

c: Daily average residual significant at the 0,99 level.

'negative news' group, statistically significant negative abnormal returns are observed between 8 and 10 days preceding the dividend announcement. These results suggest that substantial information may have reached the market prior to the actual dividend announcement as a result of active trading by insiders. These results are similar to an investigation by Bhana (1987) which revealed that leakage 
Table 2 Investment return residuals for omitted dividend sample during 1970-1988

\begin{tabular}{|c|c|c|c|}
\hline Day & $\begin{array}{c}\text { Daily average } \\
\text { residual }\end{array}$ & $T$ statistic & $\begin{array}{l}\text { Cumulative average } \\
\text { residual }\end{array}$ \\
\hline-20 & $+0,102$ & $+0,366$ & $+0,102$ \\
\hline-19 & $-0,351$ & $-0,760$ & $-0,249$ \\
\hline-18 & $-0,226$ & $-0,482$ & $-0,475$ \\
\hline-17 & $-0,191$ & $-0,540$ & $-0,666$ \\
\hline-16 & $-0,360$ & $-0,740$ & $-1,026$ \\
\hline-15 & $-0,198$ & $-0,520$ & $-1,224$ \\
\hline-14 & $-0,368$ & $-0,755$ & $-1,592$ \\
\hline-13 & $-0,395$ & $-0,760$ & $-1,987$ \\
\hline-12 & $-0,412$ & $-0,985$ & $-2,399$ \\
\hline-11 & $-0,505$ & $-1,117$ & $-2,904$ \\
\hline-10 & $-0,652$ & $-1,286^{*}$ & $-3,556$ \\
\hline-9 & $-0,817$ & $-1,360^{2}$ & $-4,373$ \\
\hline-8 & $-0,742$ & $-1,312^{2}$ & $-5,115$ \\
\hline-7 & $-0,927$ & $-1,360^{2}$ & $-6,042$ \\
\hline-6 & $-0,854$ & $-1,310^{4}$ & $-6,896$ \\
\hline .5 & $-1,238$ & $-1,417^{\circ}$ & $-8,134$ \\
\hline 4 & $-1,146$ & $1,525^{2}$ & $-9,280$ \\
\hline-3 & $-1,657$ & $-1,916^{b}$ & -10.937 \\
\hline-2 & $-2,334$ & $-3,126^{c}$ & $-13,271$ \\
\hline-1 & $-5,982$ & $-4,217^{c}$ & $-19,253$ \\
\hline 0 & $-4,521$ & $-3,423^{c}$ & $-23,774$ \\
\hline 1 & $-2,225$ & $-3,116^{c}$ & -25.999 \\
\hline 2 & $-1,834$ & $-2,261^{c}$ & $-27,833$ \\
\hline 3 & $-1,122$ & $-1,421^{2}$ & $-28,955$ \\
\hline 4 & $-0,918$ & $-1,381^{4}$ & $-29,873$ \\
\hline 5 & $-0,655$ & $-1,290^{\circ}$ & $-30,528$ \\
\hline 6 & $-0,462$ & $-1,106$ & $-30,990$ \\
\hline 7 & $-0,415$ & $-1,012$ & $-31,405$ \\
\hline 8 & $-0,362$ & $-0,821$ & $-31,767$ \\
\hline 9 & $-0,250$ & $-0,654$ & $-32,017$ \\
\hline 10 & $-0,191$ & $-0,453$ & $-32,208$ \\
\hline 11 & $-0,220$ & $-0,526$ & $-32,428$ \\
\hline 12 & $-0,122$ & $-0,358$ & $-32,550$ \\
\hline 13 & $-0,134$ & $-0,382$ & $-32,684$ \\
\hline 14 & $-0,141$ & $-0,393$ & $-32,825$ \\
\hline 15 & $-0,176$ & $-0,531$ & $-33,001$ \\
\hline 16 & $-0,212$ & $-0,488$ & $-33,213$ \\
\hline 17 & $-0,160$ & $-0,430$ & $-33,373$ \\
\hline 18 & $-0,083$ & $-0,213$ & $-33,456$ \\
\hline 19 & $-0,062$ & $-0,197$ & $-33,518$ \\
\hline 20 & $-0,120$ & $-0,375$ & $-33,638$ \\
\hline
\end{tabular}

a: Daily average sesidual significant at the 0,90 level.

b: Daily average residual significant at the 0.95 level.

c: Daily average residual significant at the 0,99 level.

of inside information occurs at a significant level in the $\mathbf{1 5}$ trading days preceding the public announcement of proposed company take-overs.

Additional information about the significance of the market reaction to the 'negative news' groups is provided by the comparative period analysis displayed in Table 3. For large dividend decreases, significant negative abnormal performance is evident for the 10-day periods preceding and
Table 3 Comparative period analysis of market reaction to announcements related to major shifts in dividend policy

\begin{tabular}{lccccc}
\hline \multirow{2}{*}{ Dividend policy } & \multicolumn{4}{c}{ Values for specific imervals (days) } \\
\cline { 2 - 5 } & $(-20,-11)$ & $(-10,-2)$ & $(+2,+10)$ & $(+11,+20)$ \\
\hline Large dividend decrease & $-1,128$ & $-5,762^{\circ}$ & $-3,633^{c}$ & $-0,514$ \\
Omitted dividends & $-1,436^{\circ}$ & $-6,145^{\circ}$ & $-3,424^{\circ}$ & $-1,120$ \\
Large dividend increase & 0,250 & $+3,825^{\circ}$ & $+1,403^{\circ}$ & $+0,412$ \\
Resumption of dividends & 0,324 & $+4,436^{\circ}$ & $+1,495^{\circ}$ & $+0,595$ \\
\hline a: significant at the 0,90 level & & & \\
b: significant at the 0,99 level & & & \\
\hline
\end{tabular}

following the dividend announcement date. In the case of omitted dividends, the t-statistics are negative and statistically significant for the 20-day period preceding and the 10-day period following the announcement date.

There is the possibility that other unfavourable news releases (related to the companies in the sample) during the pre-announcement period caused the unfavourable market reaction. A search of the news media that report on company matters revealed that only a few unfavourable announcements were released for both samples combined. Therefore, unfavourable news releases do not explain the negative market reaction associated with substantial dividend reductions. Excluding insiders, it appears that the market's lack of anticipation of the news related to dividend reductions and its subsequent informational content accounts for the market's dramatic reaction to large dividend reductions. Even though dividend reductions generally occur only after earnings have been depressed for some time, these announcements still constitute a surprise.

The market reaction to companies that announced large dividend increases and companies that resumed dividends is shown in Tables 4 and 5 respectively. The average abnormal return for the announcement days (day -1 and day 0 ) is $4 \%$ for large dividend increases and 5,4\% for companies that resumed dividend payments. In each case, the average residual is significantly different from zero at the 0,05 level of significance or higher. In the 19 trading days preceding the dividend announcement, the CAR increases by approximately $6 \%$ for large dividend increases and by $7,1 \%$ for dividend resumptions. Over the 41-day period, the CAR increases by $21,7 \%$ for resumed dividends and by $16,4 \%$ for large dividend increases. The market response to dividend resumptions is much more pronounced than for large dividend increases. Large dividend increases may be anticipated by companies performing extremely well. However, dividend resumptions may be more difficult to predict and, thus, surprise the market.

The pattern of results for the four groups are quite similar. For each group, there appears to be large excess returns during the month prior to the day of the announcement (day $t=-1$ and $t=0$ ). For the groups with large dividend decreases and dividend omissions, these excess returns are substantial, $-11,3 \%$ and $-13,3 \%$ respectively. On an annualized basis these two excess returns are $135,6 \%$ 
Table 4 Investment return residuals for large dividend increase sample (minimum increase of $40 \%$ ) during 1970-1988

\begin{tabular}{|c|c|c|c|}
\hline Day & $\begin{array}{l}\text { Daily average } \\
\text { residual }\end{array}$ & T statistic & $\begin{array}{c}\text { Cumulative average } \\
\text { residual }\end{array}$ \\
\hline .20 & $-0,189$ & $-0,514$ & $-0,189$ \\
\hline-19 & $+0,144$ & $+0,390$ & $-0,045$ \\
\hline-18 & $-0,286$ & $-0,669$ & $-0,331$ \\
\hline-17 & $+0,098$ & $+0,340$ & $-0,233$ \\
\hline-16 & $+0,179$ & +0.428 & $-0,054$ \\
\hline-15 & $+0,224$ & $+0,473$ & $+0,170$ \\
\hline-14 & $-0,369$ & $-0,753$ & $-0,199$ \\
\hline-13 & $-0,456$ & $-1,056$ & $-0,655$ \\
\hline-12 & $+0,254$ & $+0,669$ & $-0,401$ \\
\hline-11 & $-0,364$ & $-0,760$ & $-0,765$ \\
\hline-10 & $+0,283$ & $+0,693$ & $-0,482$ \\
\hline-9 & $+0,342$ & $+0,741$ & $-0,140$ \\
\hline .8 & $+0,465$ & $+1,065$ & $+0,325$ \\
\hline-7 & $+0,491$ & $+1,090$ & $+0,816$ \\
\hline-6 & $+0,440$ & $+1,026$ & $+1,256$ \\
\hline-5 & $+0,796$ & $+1,332^{2}$ & $+2,052$ \\
\hline-4 & $+1,096$ & $+1,497^{\circ}$ & $+3,148$ \\
\hline-3 & $+1,206$ & $+1,535^{4}$ & $+4,354$ \\
\hline-2 & $+1,641$ & $+1,916^{b}$ & $+5,995$ \\
\hline-1 & $+2,167$ & $+3,020^{\circ}$ & $+8,162$ \\
\hline 0 & $+1,840$ & $+2,290^{b}$ & $+10,002$ \\
\hline 1 & $+1,431$ & $+1,714^{\circ}$ & $+11,433$ \\
\hline 2 & $+1,168$ & $+1,489^{\circ}$ & $+12,601$ \\
\hline 3 & $+0,987$ & $+1,418^{2}$ & $+13,588$ \\
\hline 4 & $+0,764$ & $+1,349^{\circ}$ & $+14,352$ \\
\hline 5 & $+0,521$ & $+1,126$ & $+14,873$ \\
\hline 6 & $+0,289$ & $+0,721$ & $+15,162$ \\
\hline 7 & $+0,315$ & $+0,764$ & $+15,477$ \\
\hline 8 & $+0,106$ & $+0,350$ & $+15,583$ \\
\hline 9 & $+0,120$ & $+0,382$ & $+15,703$ \\
\hline 10 & $+0,010$ & $+0,035$ & $+15,713$ \\
\hline 11 & $+0,080$ & $+0,281$ & $+15,793$ \\
\hline 12 & $+0,069$ & $+0,246$ & $+15,862$ \\
\hline 13 & $+0,120$ & $+0,359$ & $+15,982$ \\
\hline 14 & $+0,169$ & $+0,424$ & $+16,151$ \\
\hline 15 & $+0,145$ & $-0,401$ & $+16,296$ \\
\hline 16 & $+0,178$ & $+0,553$ & $+16,474$ \\
\hline 17 & $-0,069$ & $-0,230$ & $+16,405$ \\
\hline 18 & $-0,042$ & $-0,150$ & $+16,363$ \\
\hline 19 & $+0,189$ & $+0,472$ & $+16,552$ \\
\hline 20 & $-0,096$ & $-0,342$ & $+16,456$ \\
\hline
\end{tabular}

a: Daily average residual significant at the 0,90 level.

b: Daily average residual significant at the 0,95 level.

c: Daily average residual significant at the 0,99 level.

and $159,6 \%$ respectively. The excess retums prior to the day of announcement for the groups with large dividend increases and dividend resumptions are $6,0 \%$ and $7,1 \%$ respectively. On an annualized basis these two excess returns are $72,0 \%$ and $85,2 \%$ respectively. Further, these excess returns seem to be concentrated largely during the last ten days prior to the dividend announcement.
Table 5 Investment return residuals for dividend resumptions sample during 1970-1988

\begin{tabular}{|c|c|c|c|}
\hline Day & $\begin{array}{l}\text { Daily average } \\
\text { residuals }\end{array}$ & T statistic & $\begin{array}{l}\text { Cumulative average } \\
\text { residual }\end{array}$ \\
\hline-20 & $-0,127$ & $-0,412$ & $-0,127$ \\
\hline-19 & $-0,225$ & $-0,490$ & $-0,352$ \\
\hline-18 & $+0,138$ & $+0,460$ & $-0,214$ \\
\hline-17 & $+0,360$ & $+0,733$ & $+0,146$ \\
\hline-16 & $-0,245$ & $-0,514$ & $-0,099$ \\
\hline-15 & $-0,196$ & $-0,475$ & $-0,295$ \\
\hline-14 & $+0,019$ & $+0,068$ & $-0,276$ \\
\hline-13 & $+0,166$ & $+0,411$ & $-0,110$ \\
\hline-12 & $-0,191$ & $+0,475$ & $-0,301$ \\
\hline-11 & $-0,069$ & $-0,232$ & $-0,370$ \\
\hline-10 & $+0,386$ & $+0,779$ & $+0,016$ \\
\hline-9 & $+0,431$ & $+0,947$ & $+0,447$ \\
\hline-8 & $+0,457$ & $+1,066$ & $+0,904$ \\
\hline-7 & $+0,503$ & $+1,103$ & $+1,407$ \\
\hline-6 & $+0,542$ & $+1,128$ & $+1,949$ \\
\hline-5 & $+0,850$ & $+1,326^{2}$ & $+2,799$ \\
\hline-4 & $+1,140$ & $+1,499^{\circ}$ & $+3,939$ \\
\hline-3 & $+1,436$ & $+1,735^{\circ}$ & $+5,375$ \\
\hline-2 & $+1,761$ & $+2,137^{b}$ & $+7,136$ \\
\hline-1 & $+2,954$ & $+3,452^{c}$ & $+10,090$ \\
\hline 0 & $+2,466$ & $+3,314^{c}$ & $+12,556$ \\
\hline 1 & $+2,260$ & $+3,271^{\mathrm{c}}$ & $+14,816$ \\
\hline 2 & $+1,828$ & $+2,368^{c}$ & $+16,644$ \\
\hline 3 & $+1,364$ & $+1,672^{6}$ & $+18,008$ \\
\hline 4 & $+0,926$ & $+1,415^{\circ}$ & $+18,934$ \\
\hline 5 & $+0,663$ & $+1,311^{\circ}$ & $+19,597$ \\
\hline 6 & $+0,482$ & $+1,123$ & $+20,079$ \\
\hline 7 & $+0,367$ & $+0,750$ & $+20,446$ \\
\hline 8 & $+0,131$ & $+0,423$ & $+20,577$ \\
\hline 9 & $+0,289$ & $+0,704$ & $+20,866$ \\
\hline 10 & $+0,036$ & $+0,102$ & $+20,902$ \\
\hline 11 & $+0,114$ & $+0,350$ & $+21,016$ \\
\hline 12 & $+0,274$ & $+0,601$ & $+21,290$ \\
\hline 13 & $+0,134$ & $+0,443$ & $+21,424$ \\
\hline 14 & $+0,214$ & $+0,560$ & $+21,638$ \\
\hline 15 & $+0,169$ & $+0,472$ & $+21,807$ \\
\hline 16 & $+0,036$ & $-0,110$ & $+21,843$ \\
\hline 17 & $+0,198$ & $+0,492$ & $+22,041$ \\
\hline 18 & $-0,086$ & $-0,253$ & $+21,995$ \\
\hline 19 & $-0,135$ & $-0,396$ & $+21,820$ \\
\hline 20 & $-0,097$ & $-0,238$ & $+21,723$ \\
\hline
\end{tabular}

a: Daily average residual significant at the 0,90 level.

b: Daily average residual significant at the 0,95 level.

c: Daily average residual significant at the 0,99 level.

Comparing the market reactions to large dividend decreases and large dividend increases reveals an interesting pattern. The relatively weak positive reactions to dividend increases coupled with strong negative reactions to dividend decreases of a similar magnitude indicate that the market reacts more dramatically to negative than to positive dividend changes. The differential reaction to 'negative news' and 'positive news' dividend announcements may be explained 
by the 'overreaction hypothesis' proposed by De Bondt and Thaler (1985). This hypothesis holds that investors consistently overreact to company-specific unfavourable news (such as dividend reductions). An investigation by Bhana (1989) revealed that the JSE does not appear to overreact to news of a favourable nature. However, the JSE appears to be inefficient in reacting to the announcement of companyspecific news which is unfavourable. The findings of this investigation are also in agreement with the conclusion reached by Ghosh and Woolridge that 'shareholders consistently overreact to dividend cuts, regardless of the motive' (1989: 33).

A further point of interest is the efficiency of the JSE in reacting to the public announcement of dividend changes. According to the efficient market hypothesis (EMH), the faster the market reacts to company announcements, the more efficient the market (Fama, 1970). In terms of this criterion, the JSE appears to be inefficient in reacting to the public announcement of major dividend changes. For each sample group, there appears to be some additional share price adjustments, in the direction consistent with the announcement, for the 20 days following the announcement. These adjustments are $-9,8 \%,-9,9 \%, 6,4 \%$ and $9,2 \%$ respectively, for large dividend decreases, dividend omissions, large dividend increases, and dividend resumptions. These results do not support the semi-strong from EMH since the market reaction to dividend announcements continue for a period of up to 19 trading days after the event. This pattern is especially clear around dividend omissions and large dividend decreases.

The EMH also suggests that investors acting on publicly available information should not be able to gain a return consistently in excess of the security's risk-adjusted return. The evidence of this investigation is not consistent with the hypothesis that the JSE has been efficient in interpreting major dividend changes during the 1970-1988 period. The empirical evidence indicates that large excess returns could have been earned in the short-term ( 20 days) by buying (selling short) shares of companies that announced large dividend increases (decreases). A systematic trader in dividend changing shares would have earned significant abnormal returns even though the market had effected on average, large corrections before, and at the announcement date. This pattern is especially clear around dividend omissions and large dividend decreases.

\section{Conclusion}

The market reaction to substantial changes in dividend policy has been investigated in this article. Prior to the dividend announcements for all four groups, there is a price adjustment consistent with subsequent change in dividend policy. No matter what the cause of the 'anticipatory' abnormal retums observed prior to the dividend-change announcement, it is not totally anticipated and it does convey information. The 'announcement' effect, as defined in this article, is large and statistically significant. For the 'positive news' groups, the sample of dividend resumptions and the $40 \%$ increase, the sum of the day $\mathrm{t}=-1$, and $\mathrm{t}=0$ abnormal returns are $5,4 \%$ and $4,0 \%$ respectively. For the 'negative news' groups, the samples with $40 \%$ decreases and omis- sions, these announcement effects are much larger i.e. $-8,2 \%$ and $-10,5 \%$ respectively. It seems reasonable to conclude that there is a significant altering of investor expectations due to the dividend change announcement.

The results of this investigation provides strong support for the information content of dividend hypothesis. The empirical evidence suggests that large dividend changes on the JSE convey valuable information to investors over and above that contained in the eamings announcements. The hypothesis that investors revise their expectations in response to announcement of significant dividend changes (signalling effect) is accepted. Black (1976) reports that several researchers regard the information role of dividends as unimportant. They suggest that equally efficient, cheaper alternatives exist through which managers can disseminate information to shareholders. The results of this study demonstrate that dividend announcements convey information over and above that contained in other announcements.

Dividend policy has several attractive aspects as an information transmission mechanism. Unlike the detailed focus of other announcements, dividends can be used as a simple, comprehensive signal of management's interpretation of the company's recent performance and its future prospects. Unlike most announcements, dividend announcements must be backed with cash payments. The company must either generate this cash or convince the capital market to supply it. In addition to the credibility of cash signals, dividends are also highly visible compared with other announcements. An advantage of dividends for investors is the fixed, periodic nature of the announcements. Once dividends are initiated, shareholders anticipate a periodic signal by management, and management is forced to submit to a periodic review.

The findings of this article are consistent with the overreaction hypothesis which states that the market's reaction to unfavourable announcements is much greater than for favourable announcements. The difference in announcement effect between positive and negative news groups may be partially due to an asymmetric reaction of risk-averse investors. These inveswors are unduly concerned with the preservation of their investment capital. Therefore, unfavourable news contained in the dividend announcement may well induce investors to sell quickly in an effort to minimize their losses. A similar rapid purchase activity upon dissemination of positive dividend news is unlikely. Furthermore, it is possible that the difference in magnitudes is a result of bad news in general attracting more publicity and response than good news.

\section{Acknowledgements}

The financial assistance of the Institute for Research Development of the Human Sciences Research Council towards this research is hereby acknowledged. Opinions expressed in this publication and conclusions arrived at, are those of the author, and do not necessarily represent the views of the Institute for Research Development or the Human Sciences Research Council. 


\section{References}

Aharony, J. \& Swary, I. 1980. Quarterly dividend and earnings announcements and stockholders returns: an empirical analysis. J. Fin., Vol. 35, 1-12.

Asquith, P. \& Mullins, D.W. 1983. The impact of initiating dividend payments on shareholders' wealth. J. Bus., Vol. 56, 77-96.

Banesh, G.A., Keown, A.J. \& Pinkerton, J.M. 1984. An examination of market reaction to substantial shifts in dividend policy. J. Fin. Research, Vol. 7, 131-142.

Bhana, N. 1987. Take-over announcements and insider trading activity on the Johannesburg Stock Exchange. S. Afr. J. Bus. Mgmt., Vol. 18, 198-208.

Bhana, N. 1989. Price adjustments on the Johannesburg Stock Exchange for unexpected and dramatic news events: an empirical analysis. S. Afr. J. Bus. Mgmt, Vol. 20, 119-128.

Black, F. 1976. The dividend puzzle. J. Portfolio Management, Vol. 2, 5-8.

Bowman, R.C. 1983. Understanding and conducting event studies. J. Bus. Fin. and Account., Vol. 10, 561-584.

Brown, SJ. \& Wamer, J.B. 1980. Measuring security price performance. J. Fin. Econ., Vol. 8, 205-258.

Charest, G. 1978. Dividend information, stock returns and market efficiency. J. Fin. Econ., Vol. 6, 297-330.

De Bondt, W.F. \& Thaler, R.H. 1985. Does the stock market overreact? J. Fin., Vol. 40, 793-805.

Dielman, T.E. \& Oppenheimer, H.R. 1984. An examination of investor behaviour during periods of large dividend changes. J. Fin. and Quantitative Analysis, Vol. 19, 197-216.

Fama, E.F. \& Babiak, H. 1968. Dividend policy: An empirical analysis. J. Amer. Stat. Ass., Vol. 63, 1132-1161.

Fama, E.F. 1970. Efficient capital markets: A review of theory and empirical work. J. Fin., Vol. 25, 383-417.

Ghosh, C. \& Woolridge, J.R. 1989. Stock market reaction to growth-induced dividend cuts : Are investors myopic? Managerial and Decision Economics, Vol. 10, 25-35.
Gonedes, NJ. 1978. Corporate signalling, external accounting, and capital market equilibrium: Evidence of dividends, income and extraordinary items. J. Account. Research. Vol. 16, 26-79.

Knight, R. F. \& Affleck-Graves, J.F. 1987. An evaluation of dividend signalling on the Johannesburg Stock Exchange. S. Afr. J. Bus. Mgmı, Vol. 18, 79-86.

Laub, P.M. 1976. On the information content of dividends. $J$. Bus., Vol. 49, 73-80.

Lintner, J. 1956. Distribution of incomes of corporations among dividends, retained earnings and taxes. Amer. Econ. Rev., Vol 46, 97-133.

Lintner, J. 1965. The valuation of risk assets and the selection of risky investments in stock portfolios and capital budgets. Rev. Econ. and Statis., Vol. 47, 13-37.

Miller, M. \& Modigliani, F. 1961. Dividend policy, growth and the valuation of shares. J. Bus., Vol. 34, 411-433.

Pettit, R.R. 1972. Dividend announcements, security performance, and capital market efficiency. J. Fin., Vol. 27, 993-1007.

Roll, R. 1977. A critique of asset pricing theory's test; Part 1: On past and potential testability of the theory. J. Fin. Econ., Vol. 4, 129-176.

Sharpe, W.F. 1964. Capital asset prices: A theory of market equilibrium under conditions of risk. J. Fin., Vol. 19, 425-442.

Venkatesh, P.C. 1989. The impact of dividend initiation on the information content of earnings announcements and retums volatility. J. Bus., Vol. 62, 175-197.

Watts, R. 1973. The information content of dividends. J. Bus., Vol. 46, 191-211.

Watts, R. 1976. Comments on 'The impact of dividends and earnings announcements: A reconciliation. J. Bus., Vol. 49, 97-106.

Woolridge, J.R. 1982. The information content of dividend changes. J. Fin. Research, Vol 5, 237-247. 